\title{
Arnošt Lustig a ti druzí
}

\author{
Jiří Holý
}

\section{AbSTRACT}

\section{Arnošt Lustig and Others}

This article examines changes in the Holocaust/Shoah presentation in literature throughout the several past decades. According to Alvin H. Rosenfeld, the Holocaust is not percieved as an authentic historical event these days and slowly becomes a shared symbol of evil or entertainment. Rosenfeld warns about the possible "end of the Holocaust" in public consciousness.

Short stories and novels by Arnošt Lustig are good examples of these changes. Later books by the author accentuate the harsher side of life in the camps (violence, brutality, hetero- and homosexual prostitution, lack of unity among the prisoners etc.). He often records stories of young Jewish girls and women. Their beauty and youth form a moving contrast to the horrors of the Shoah. In the novelette Colette, for instance, many conventional images are used in the narrative. Credibility of presented figures disappears very often, they are "omnipresent" and "omniscient" almost like the famous Forrest Gump. By using various information and statements reproduced by these characters, the author constructs a kind of Auschwitz-Birkenau encyclopedia. The result of this is the loss of authenticity. At the same time, though, a lot of data of this "encyclopedia" is inaccurate.

Lustig uses elements of thriller and romance. In works by other well-known authors who write about the Holocaust, various elements can be found: elements of thriller (Jonathan Littell), fantasy, comics, horror as well as porn films (Igor Ostachowicz). Literary texts by both Littel and Ostachowicz are full of violence, brutality and sexual scenes. Like Lustig, Jonathan Littell has created an encyclopedia of Nazi crimes during the WWII with implausible characters and situations in his novel The Kindly Ones. In contrast to Lustig and Littell, Night of the Living Jews by Ostachowicz is more original and impressive. It also brings actual questions concerning the past and relations between Poles and Jews.

\section{KEYWORDS}

Holocaust/Shoah, literature, film, Arnošt Lustig.

\section{KLÍčOVÁ SLOVA}

Holokaust/šoa, literatura, film, Arnošt Lustig. 
1.

Námětem této úvahy jsou proměny zobrazení v literárních dílech s tematikou holokaustu. Aleida Assmannová píše, že kultura paměti holokaustu prodělala „etický obrat"; kategorie jako obět, přeživší a svědek získaly od devadesátých let minulého století vysoký morální status. Holokaust se na přelomu tisíciletí proměnil v euroamerické civilizaci v globální obraz, obecně reprezentuje nelidskost ve vztahu k univerzálním normám mravnosti (AssMANN 2006: 79; AssMANN 2010: 98, 109). Rovněž podle Alvina Rosenfelda se z „autentické historické události“ stále více stává „obecným symbolem“ a „entertainmentem“ (ROSENFELD 2011: 15). Rosenfeld varuje před možným „koncem holocaustu“ v obecném vědomí.

S tím souvisí to, co se někdy nazývá „amerikanizace“ holokaustu. Holokaust se dnes objevuje v podobách a žánrech, které byly v prvních poválečných desetiletích s šoa neslučitelné, jako mainstreamová filmová romance, opereta, dokonce i dětská stavebnice atd. Populární média manipulují s historickými událostmi a vedou nás do simplifikovaného světa. Mưžeme to připsat faktu, že „pamět holokaustu" už není primárně formována svědectvím přeživších, ale neadekvátními obrazy filmařů a romanopisců, kteří vlastní zkušenost $\mathrm{s}$ těmito událostmi nemají. Někdy se spojuje s prvky hororu, ba i pornografie. O tom svědčí už samy názvy filmů jako Cannibal Holocaust (1980, režie Ruggero Deodato) či Porno Holocaust (1981, režie Joe D’Amato). V obou nepadne o Židech a jejich vyhlazování ani slovo, nicméně využívají „značku“ holokaustu jako hrůzné, nesouměřitelné a zároveň atraktivní události. Jindy se naopak šoa idylizuje, jakoby přibližuje světu současných čtenářů a diváků. Vznikají tzv. soft verze holokaustu s ušlechtilými postavami typu Oskara Schindlera, nevinnými dětmi, jako jsou německý a židovský chlapec v knize i filmu Chlapec v pruhovaném pyžamu (autor prózy z roku 2006 John Boyne, režie filmu Mark Herman, 2008), nebo přitažlivými kráskami, jako jsou četné hrdinky Arnošta Lustiga. V románech, ve kterých se objevuje vyhlazení Židů jako téma či dílčí motiv, se často uplatňují postupy žánrů popkultury, jako jsou thriller, erotický román či fantasy. Svědčí o tom tak rozdílná díla, jako jsou Topolova Sestra (1994), Ostachowiczova Noc živých Židů (viz dále) nebo Sidonova rozsáhlá tetralogie Kde lišky dávají dobrou noc (2014, 2015, 2016 a 2017). 


\section{2.}

Dílo Arnošta Lustiga je dobrým příkladem pro proměňující se prezentaci literatury s tématem holokaustu od konce padesátých let minulého století po první desetiletí století našeho. Lustigovy pozdější knihy zdůrazňují temnou stránku života $\mathrm{v}$ ghettech a koncentračních táborech, násilí, brutalitu, prostituci a homosexuální prostituci, nedostatek solidarity mezi vězni. Po Ditě Saxové a Kateřině Horovitzové se vracejí příběhy žen a dívek, jejichž krása a mládí vytváří kontrast $\mathrm{k}$ hrůzám šoa. Taková je patrně jediná kniha, která nově vznikla během dvaceti let Lustigova exilu, Nemilovaná (1979), s podtitulem $Z$ deníku sedmnáctileté Perly Sch., fiktivní deníkové zápisky mladé židovské prostitutky v terezínském ghettu. Spojuje naivitu pisatelky s obrazem drsného života v Terezíně v druhé polovině roku 1943.

„16. listopadu. Dvakrát. Svíčka a zápalky. Sítka na vlasy. Krabice suchého lihu. Třikrát. Čtvrtka žitného chleba. Dvě deka margarínu. Teploměr. Plechový koflík. Litrová termoska“ (Lustig 1991: 63).

Lakoničnost záznamů se opakuje v pozdějším románu Krásnézelenéoči (2000). Hrdinkou je opět mladičká židovská prostitutka, patnáctiletá Hanka Kudersová čili Kůstka, tentokrát v polním nevěstinci u řeky San v jihovýchodním Polsku: „Patnáct: Herrmann Hammer, Fritz Blücher, Reinhold Wupperthal, Siegfried Fuchs..." (Lustig 2003: 7).

Mezitím v letech 1992 až 1998 vyšla, kromě jiných děl, trojice novel, které autor spojil do „židovské trilogie“, s obdobným typem ženských hrdinek. Zde se variují a ještě stupňují konvenční postupy autorových předchozích děl, na které kritika (Milan Suchomel, Josef Vohryzek, Jiří Opelík, Milan Jungmann) upozorňovala už v šedesátých letech: sáhodlouhé, nepřirozené dialogy, opakované motivy i situace a reflexe vypravěče či postav, které těžko označit jinak než jako banální.

\footnotetext{
.„Jsem?“

„Jsi,“ odpověděl jí V. F.

„Z masa a krve?"

„Z masa a krve“ (LUSTIG 2013: 76-77) .

„Proč bůh stvořil tebe a mne?“ (IBID.: 151)
} 
Vypravěč tato klišé komentuje: „Slova měla deset dalších významů“ (IBID.: 9), později dokonce „Každá zmínka o čistotě měla sto významů“ (IBID.: 150). Takové komentáře a dialogy vzbuzují dojem, že mezní situace koncentračních táborů vězně přivádějí $\mathrm{k}$ hlubokým myšlenkám. Ve skutečnosti jsou ale nevěrohodné a triviální.

V pozdním díle Lustig častěji než dřive používá opakující se obrazy a fráze. Například už na počátku novely Colette se objevuje srovnání hrdinky s ptáky. To se pak mnohokrát opakuje:

\footnotetext{
„Měla v očích rozpětí křídel ptáků v letu. Dráhu odněkud někam. [...] Po celých devět měsíců, co ji znalo pár lidí v Auschwitz-Birkenau, se podobala ptáku, jemuž selhala magnetická střelka" (IBID.: 5). „Připomínala mu tažné ptáky, jimž pod křídly hoří oheň“ (IBID.: 11).
}

„Colette byla pták, který letí nad vodami mezi břehy [...] pták, který se nemůže vyhnout dravcům“ (IBID.: 26).

„Připadala si jako pták chycený do obrovské klece“ (IBID.: 34).

Tato srovnání jsou dobře známá $\mathrm{z}$ vězeňské literatury přinejmenším od Dostojevského po deník Anny Frankové a u Lustiga se častým opakováním (čteme je v jedné knize neméně než čtyřicetkrát) zploštují.

Jiný opakující se obrat se objevuje už na druhé straně Colette. „Vyšší a nižší poschodí pravdy, vyšší a nižší poschodí lži“ (IBID.: 6). V textu se pak věty o nižších a vyšších poschodích lži a pravdy v různých variacích opakují více než třicetkrát.

Vyhlazovací tábor v Osvětimi-Birkenau je v Colette popsán v mnoha, většinou drastických scénách. Nacistický dozorce Weissacker střilí pro zábavu vězně a znásilňuje mladé vězenkyně. Jeho sexuální obětí je i krásná devatenáctiletá belgická Židovka Colette. Ta se však zamiluje do českého vězně Viliho, s nímž se tajně s nasazením života schází. Filmová verze novely, kterou natočil režisér Cieslar údajně ještě za Lustigovy spoluúčasti (2013), př́ínačně zvýrazňuje brutalitu některých scén a barvitě líčí scény erotické. Mnohé výjevy a záchrana obou hrdinů na způsob hollywoodských „escape stories“ zde připomínají postupy thrilleru, k němuž nemá daleko ani prozaická předloha. Jestliže v proslulém polském filmu Pasažérka (1963, Andrzej Munk, podle předlohy Zofie Posmysz) se milenci-vězňové v osvětimském táboře drží za ruce, ve filmové verzi Colette je prezentován sex hetero- $\mathrm{i}$ homosexuální v různých pozicích.

Také v další novele Láska a tělo (2009) nacházíme dvojici milenců, osmnáctiletou Gabrielu Lábusovou a řezníka Josefa Reinische, tentokrát v terezínském ghettu. Není to u Lustiga poprvé, už povídka Štěpán a Anna v prvotině Noc a na- 
děje (1958) líčila rodící se milostný vztah dvou mladých lidí v Terezíně. V obou dílech byl tento vztah ukončen transportem na východ, v prvním případě je nečekaně deportována Anna, ve druhém odjíždějí Gabriela a Josef spolu. Zatímco však v první Lustigově knize schůzka obou milenců vyvrcholila polibkem a slibem, že se znovu sejdou, po šedesáti letech, v autorově bezmála poslední knize je v popředí jejich tělesný vztah, popisovaný prostřednictvím rozvleklých dialogů. Výrazně je tak použito prvků konvenčního milostného románu, romance. Stejně jako Colette ve stejnojmenné novele i Gabriela zde přitom cítí potřebu informovat svého partnera během milování o scestných názorech i choutkách svého předchozího milence. V Nemilované se tak ještě dálo v deníkových záznamech, což působilo nejen vkusněji, ale také hodnověrněji.

Colette a Láska a tělo mají společné i to, že - jako bývá časté v Lustigových pozdních dílech - vytvářejí jakousi encyklopedii osvětimského tábora či terezínského ghetta. Děje se tak prostřednictvím postav, které místy působí jako všudybylové či všeználci. Například Colette (o níž v uvedeném citátu vypravěč uvádí, že ji v Osvětimi znalo „pár lidí“): „Znala muže ze Sonderkommanda, kteří pracovali v krematoriu, pekaře $z$ pekáren, ševce $z$ ševcáren, vykladače vagonů, zřízence z rampy“ (IBID.: 65). Colette pracovala v tzv. Kanadě, kde se třídily cenné věci příchozích, jako peníze, zlato a šperky. Byla obyčejnou vězenkyní, ne kápem či vorarbeitrem, a nemohla mít takové kontakty. Je zcela nepravděpodobné, že by znala vyjmenované lidi. Zvláště členové sonderkomanda byli striktně izolováni od ostatních. Ovšem vypravěč potřebuje nějak vysvětlit informace o různých událostech $\mathrm{z}$ tábora, které podává, a toto je prostý způsob, který už používali autoři 18. a 19. století. Colette zná dokonce Himmlerovy tajné instrukce, které neznali ani běžní členové zbraní SS: „Podle Himmlerova tajného rozkazu se mělo přestat plynovat. Budou chtít vyhodit plynové komory do povětří? Zatím se plynovalo dál jako předtím. Nezdálo se, že by esesačky byly v říjnu méně zpupné než v září“ (IBID.: 147).

Ale nejen Colette, také Vili Feld a německý poddůstojník Weissacker jsou jako proslulý Forrest Gump u všeho přítomni, nebo aspoň o všem důležitém v táboře vědí: „Vili věděl, že je tu padělatelská dílna, kde nacisti vyrábějí anglické a americké peníze..." (IBID.: 73). Šlo o přísně tajnou Operation Bernhard, jejímž cílem bylo destabilizovat britskou ekonomiku falešnými bankovami. Jenom několik předních nacistů bylo do tohoto plánu zasvěceno. Weissacker má zase informaci o tajných nacistických kontech ve Švýcarsku. „Myslel na tajná konta, švýcarské účty na heslo. Velké bohatství propadlo mlčenlivým švýcarským peněžním ústavům“ (IBID.: 79). To je myšlenkový obzor, který přesahuje možnosti nacistického 
unterscharführera (poddůstojník na úrovni kaprála). Weissacker je primitivní sadista, který zabijí vězně a znásilňuje vězenkyně. Je ovšem také zapojen do bizarního programu Lebensborn, který se objevuje i v dalších Lustigových prózách i jinde (Hrabalova próza Obsluhoval jsem anglického krále; Cieslarův film Pramen života, níže uvedené Laskavé bohyně). Navíc je Weissacker př́tomen i při Himmlerově návštěvě v Osvětimi. „Překvapilo ho, že nejvyšší říšský vedoucí u okénka $\mathrm{z}$ tlustého skla do plynové komory málem omdlel. Museli mu rychle přistavit židli“ (IBID.: 109). Je krajně nepravděpodobné, že by se ve svitě doprovázející reichsführera objevil spolu s vysokými důstojníky unterscharführer z tzv. Kanady. Vedle toho se Himmlerova návštěva odehrála předtím, než Weissacker podle novely do tábora nastoupil. Je to jenom jedna $z$ více historických nepřesností v této novele (např. v říjnu 1944 nebyl Rudolf Höß velitelem Osvětimi; v Osvětimi neumíralo od roku 1941 každý den deset tisíc vězňů). Sám Arnošt Lustig prožil válku v ghettu Terezín a v koncentračních táborech (v Osvětimi strávil čtyři dny), a byl proto považován za jakousi garanci dějinné hodnověrnosti svých příběhů. Nedbalost vůči historickým faktům můžeme vysvětlit chvatem, s nímž svá pozdní díla dodával na knižní trh, a snad také tím, že holokaust pro něho postupně přestával být součástí osobní nezaměnitelné zkušenosti a stával se obecným symbolem v tom smyslu, jak to ve své knize popsal Alvin H. Rosenfeld.

\section{3.}

O tom, že Lustigova prezentace tématu holocaustu není v současné literatuře ojedinělá, svědčí srovnání se dvěma slavnými a ceněnými romány, Laskavými bohyněmi francouzského autora se židovskými předky Jonathana Littella (v originále Les Bienveillantes, 2006, česky 2008) a fantaskním románem Noc živých Židů polského autora Igora Ostachowicze (v originále Noc żywych Żydów, 2012).

Laskavé bohyně jsou fiktivní memoáry muže jménem Maximilien Aue. Aue je doktor práv, vzdělanec, ale také obersturmbannführer SS. Stane se příslušníkem speciálních komand (Einsatzgruppen) na východní frontě, která měla za úkol likvidovat Židy a „komisaře“, později působí jako zvláštní Himmlerův pověřenec, který kontroluje vyhlazovací tábory v Polsku. Své vzpomínky na válečnou dobu píše s odstupem několika desetiletí ve Francii, kde spořádaně žije jako majitel továrny v penzi. (Po válce změnil identitu a vydával se za francouzského dělníka donuceného pracovat v Německu. Podařilo se to snadno, protože pocházel z Alsaska, jeho matka byla Francouzka a od dětství byl bilingvní.) 
Román stejně jako zmíněná pozdní Lustigova díla využívá stylistické i narativní postupy thrilleru. Vypravěč prochází těmi nejdrsnějšími válečnými zkušenostmi, sleduje krvavý pogrom ve Lvově, účastní se masového vraždění Židů v Babim Jaru, dostává se k obležené Paulusově armádě ve Stalingradu, navštěvuje vyhlazovací tábory smrti v Polsku, Hitlerův hlavní stan na konci války v obleženém Berlíně. I v tom se podobá uvedeným Lustigovým postavám, spíše než hodnověrnou postavu připomíná loutku, na niž se navěšují situace, které demonstrují hrůzy války a šoa. Také Laskavé bohyně jsou svým způsobem encyklopedií historických událostí a postav, avšak na rozdíl od Lustigových děl, kde lze dost často najít situace odporující doloženým dějinným faktům, historicky přesnou. Jako by však ani tyto extrémní situace nestačily, proživá a popisuje je postava neméně extrémní: Max Aue je nejen erudovaný intelektuál, který umí latinsky a řecky, je nadaný pianista a znalec hudby, filozofie a literatury, ale také homosexuál, který v dětství ztratil otce, prožil osudový incestní vztah se sestrou a patrně zavraždil svou matku i nevlastního otce. Některé Maxovy činy se přitom vymykají i mezním kritériím pravděpodobnosti, např. na konci války v berlínském hotelu brutálně zavraždí jakéhosi šlechtice, svého známého a homosexuála, jenom proto, že mu připadá dotěrný a ješitný; vzápětí při setkání s Hitlerem kousne Vůdce do nosu, je zatčen, ale při zmatku těsně před německou kapitulací vyvázne.

Na straně druhé román rafinovaně pracuje s prvky fantaskní a reflexivní literatury. Vedle toho obsahuje výjevy bestiálního masového i individuálního vraždění, sadismu, perverzí a orgií, kanibalismu, sebevražd německých vojáků, kteří se nedokážou vyrovnat se svými „bojovými úkoly“ ve speciálních komandech, atd.

„Písčitá zem kolem mrtvol byla nasáklá začernalou krví, i potok byl černý od krve. Nad pachem krve převládal příšerný zápach fekálií, protože mnozí se v okamžiku smrti pokáleli; naštěstí foukal silný vítr, který tyhle závany částečně odnášel. [...] Jak jsem šlapal po tělech Židů, měl jsem stejný pocit, stř́lel jsem téměř nazdařbůh po všem, co se pohnulo, pak jsem se vzchopil a zkusil dávat pozor, bylo potřeba, aby lidé trpěli co nejméně, ale já se stejně dostal jen k těm nejčerstvějším, pod nimi byli jiní ranění, kteří ještě žili, moc života jim však už nezbývalo“ (LITTELL 2008: 116-117).

„Když jsem se vracel nahoru, byla tma a já si spletl pokoj; bylo otevřeno, a tak jsem vešel dovnitř: v posteli souložili dva muži a jedna dívka, jeden z mužů ležel na zádech, druhý klečel, dívka mezi nimi rovněž klečela. Chvilku mi trvalo, než jsem pochopil, co to vidím, a když se konečně věci jako ve snu vrátily na své místo, utrousil jsem omluvu a chtěl odejít. Ten klečící muž, který na sobě neměl 
nic až na holínky, se ale zvedl a ustoupil. Se vztyčeným údem, který si zlehka třel rukou, mi, jako by mě zval na své místo, ukázal na dívčiny pủlky, mezi jejichž bílými polokoulemi zel jako mořská laguna anus obklopený růžovou aureolou“" (IBID.: 516-517).

Nadto se objevují také četné surreálné scény, které jsou produktem vypravěčovy imaginace, jsou však líčeny stejně jako scény „reálné“. Celý tento složitý fikční svět je obklopován sofistikovanými komentáři jak z hlediska prožívajícího subjektu v době války, tak vyprávějícího subjektu čtyřicet let poté. V dialozích Max rozmlouvá s Eichmannem o právu a morálce, se zajatým sovětským komisařem vede disputaci o podobnosti komunismu a nacismu a podobně. Celý př́běh navíc odkazuje $\mathrm{k}$ řecké mytologii. Titul knihy je převzatý z Aischylovy Oresteie, v níž hrdinu, který zabil svou matku (aby pomstil smrt otce), pronásledují bohyně pomsty Erínye. Erínye jsou v závěru usmířeny a nazvány „laskavými bohyněmi“ (Eumenidami). V Littellově románu funkci Erínyí mohou plnit dva kriminální vyšetřovatelé, kteří podezírají Maxe z vraždy matky a sledují ho (oba jsou na konci příběhu zastřeleni). Role Orestovy sestry Élektry pak připadá Maxově sestře se symbolickým jménem Una.

Reflexivita je patrná také v intertextualitě a množství latentních i zjevných polemických narážek. Například při setkání s Eichmannem, s nímž v jeho domácnosti popíjí čaj a poslouchá domácí koncert, vypravěč poznamenává, že tento člověk jistě nebyl inkarnací „banálního zla“. Naráží tím na slavnou knihu Hannah Arendtové o procesu s Eichmannem. V Osvětimi, kde se setkává s Rudolfem Hößem, si připomíná jeho memoáry a soudí, že to byl průměrný důstojník, umíněný a omezený, bez fantazie a nápadů, měl však v sobě něco z mužné autority. A uvažuje o tom, že Höß by mohl mít mezi německými vězenkyněmi milenku, což je doložený fakt (který Höß ve svých zápiscích zamlčel). Tyto úvahy vypravěče, psané z pozdější časové perspektivy, tvoří jakýsi druhý reflexivní rozměr románu.

Littellův román byl nadšeně přijat ve Francii, kde získal Prix Goncourt i velkou cenu Francouzské akademie, během roku a půl se prodalo 700000 exemplářů. Kritika jej označovala za znepokojivé a fascinující dílo, autora srovnávala s Dostojevským. V roce 2008 vyšla kniha v německém překladu a zde tak pozitivní ohlas nezaznamenala. Psalo se o patologickém vidění, fascinaci hrůzou, zcela nepravděpodobném hrdinovi, který je monstrózní fantom i moralizátor zároveň. Jako zvláštnost a „strategická provokace“ byla románu přiznána „perspektiva kata“, člověka, který rafinovaně relativizuje svou nepřenosnou odpovědnost za své zločiny. Takové hodnocení románu sdílí i autor tohoto článku. Soudí přitom, že perspektiva viníka není v knihách s touto tematikou novum, 
objevuje se například v románu Roberta Merla Smrt je mé řemeslo už na začátku padesátých let, $\mathrm{v}$ šedesátých letech v rozhlasové hře a próze Zofie Posmysz Pasažérka,ve Fuksově novele Spalovač mrtvol, Hilsenrathově románu Nácek a holič a v dalších dílech. I když je Littellův román $\mathrm{v}$ historických situacích, které prezentuje, autentický, zobrazení války a holokaustu z bizarního a morbidního úhlu pohledu vychází vstříc současnému kultu násilí, erotiky a sexu. I Laskavé bohyně jsou tak, stejně jako Lustigova díla, dokladem posunu prezentace holokaustu směrem k tomu, co Alvin H. Rosenfeld nazývá „entertainment“.

\section{4.}

Zcela jiným typem díla je rovněž úspěšná próza Igora Ostachowicze Noc živých Židů (2012), která v češtině dosud nevyšla. Název byl patrně inspirován Romerovým filmovým hororem Noc oživlých mrtvol (1968), který líčí boj několika vesničanů na farmě v Pensylvánii s oživlými monstry, která na ně útočí. V roce 2014 byla Ostachowiczova próza Markem Kalitou adaptována pro varšavský Teatr Dramatyczny. Jestliže fikční svět Laskavých bohyň byl situován do doby druhé světové války a vypravěč se ve svých reflexích dostával do doby o několik desetiletí pozdější, zde je tomu naopak. Fikční svět se odehrává na začátku 21. století, v kulisách současné Varšavy, ve čtvrti Muranów, kde za války stálo židovské ghetto. Zavraždění Židé, kteří tam zemřeli hladem, vyčerpáním nebo v boji při velikonočním povstání v ghettu a nikdy nebyli pohřbeni, ožívají, vynořují se z podzemí a dožadují se pozornosti živých. Zaplňují varšavské ulice. Proti nim se staví síly zla, nacionalistické a fašistické bojůvky a v obchodním centru Arkadia dochází $\mathrm{k}$ bitvě mezi silami zla a dobra. Na rozdíl od Romerova filmu jsou to oživlí mrtví, kdo jsou obléháni a musí se bránit. Na pomoc policie a polské veřejnosti příliš spoléhat nemohou. Důležitou roli v tomto boji hraje zázračná rekvizita, která přináší štěstí, stříbrné srdce, jež patřilo Židům, bylo jim ukradeno a posléze se jim a jejich spojencům vrací. Banditům se sice podaří zapálit střechu obchodního domu, ale jsou poraženi a Židé se rozcházejí jako normální lidé do varšavských domů. Vypravěč telefonuje ke své př́itelkyni, která sleduje všechny tyto události v médiích. Chce se pochlubit svým hrdinstvím, ale ona ho přerušuje a mluví o tom, co se o těchto událostech píše na internetu a ve zprávách. Během dalších bojů je vypravěč pravděpodobně zabit a stává se také zombie.

Vypravěč je bezejmenný mladý Polák, který žije ve skromném bytě s přítelkyní, kterou nazývá „Hubená“. Náhle je však konfrontován - a takřka proti své 
vůli zatažen - do velkého konfliktu. Zprvu je více zaujat velkými prsy Židovky Rejczel a přemýšlí, zda by byla ochotna k sexu. Posléze se však přidává na stranu Židů a bojuje s nimi proti silám zla.

Lustig a Littell ve svých dílech používali postupy thrilleru. Ostachowicz, v jehož vyprávění stejně jako u pozdního Lustiga a Littella dominuje úzce osobní, intimní perspektiva, používá prvky fantasy, komiksu a místy i hororu a počítačových her, zároveň však tyto žánry paroduje.

Specifickým rysem Noci živých Židů je vypravěčův jazyk, mluvená až vulgární polština, která je pro toho, kdo není rodilý mluvčí, místy těžko srozumitelná. Jazyk ovšem odpovídá celkové perspektivě textu a drsným situacím, které jsou zde líčeny. I zde, jako ve všech představených knihách, najdeme scény násilí a otevřené líčení sexu, dobrovolného i nuceného, hetero- i homosexuálního. Ale místy také komiku: oživlý polský oficír si nesmí v kavárně zapálit, nechápe to a ptá se, zda to není ještě pozůstatek nějakých nacistických nařízení; senzační zprávy o událostech v médiích mají titulky jako „Živé mrtvoly v ulicích“ nebo „Židovské mrtvoly překážejí Polákům“.

Zajímavou epizodní postavu představuje polský lékař, který se za války snažil zachránit svou židovskou snoubenku. Po brutálním zásahu gestapa je však nucen ji sám zabít, aby ji uchránil od dalšího mučení. Po její smrti se rozhodne se mstít a vraždit nacisty. Tento typ nelítostného mstitele není v literatuře příliš obvyklý; připomíná například postavy v Hanušově románu Já, spravedlnost (dílo zfilmované Zbyňkem Brynychem) nebo v Beckerově románu Bronsteinovy děti (filmová verze Jerzy Kawalerowicz) a samozřejmě také proslulé Tarantinovy Hanebné parchanty.

Jedním z pozoruhodných míst Ostachowiczova románu jsou scény situované do Osvětimi, srovnatelné snad jen s příslušnou kapitolou v Topolově románu Sestra. Ostachowiczův vypravěč se svou přítelkyní Hubenou v realitě-nerealitě fikčního světa románu se ocitá v transportu do Osvětimi-Březinky. Jejich nepřátelé, představitelé zla, je očekávají na rampě a přivítají je řevem a mlácením. Vypravěč prochází apelem, trpí hladem a je zavřen do bunkru. V táboře vidí mnoho klecí, do nichž jsou nahnány nahé vězněné ženy a spolu s nimi i nazí vězni. Ocitá se v jedné $z$ klecí i se svou přítelkyní, vidí ji netečně souložit $s$ jinými a cítí se být zvířetem (OSTACHOWICZ 2012: 139-40).

Tato scéna se posléze ukáže být rafinovanou inscenací dábelských sil zla, které se chtějí zmocnit stříbrného srdce. Snad mohla být skutečně inspirována Topolovou kapitolou I had a dream v Sestře, kde se pobyt hrdinů v Osvětimi rovněž představuje jako něco neskutečného, a přesto drtivě působivého. Ro- 
mán Sestra totiž vyšel již před časem i v polštině (2002) ve vynikajícím překladu Leszka Engelkinga.

Se Sestrou může Noc živých Židů spojovat také využití nespisovného jazyka, postupů popkultury a perspektiva „nezaujatého“ vypravěče, který se narodil řadu desetiletí po válce a události vnímá prostřednictvím již ustálených obrazů a stereotypů. Oba, Jáchym Topol i Igor Ostachowicz, jistým způsobem provokují tím, že evokují fantomy minulosti. V osvětimské kapitole Sestry je to zamlčovaná spoluvina Čechů na zločinech nacismu. V Noci živých Židů je to vztah současných Poláků k masakrům Židů, kterých se dopouštěli jejich předkové, například za války v Jedwabnem, po válce v Kielcích i jinde. Domnívám se, že je to právě tato provokující polemičnost, která Ostachowiczův román odlišuje od literatury pojímané jako „entertainment“, k níž se jinak některými svými postupy hlásí.

Všechny tři uvedené prózy spojuje to, že do textu integrují postupy thrilleru, romance, hororu a erotického románu, tedy žánrů, které tradičně nebyly součástí děl s tematikou holokaustu. Tento postup je příznačný pro literaturu i film posledních desetiletí. Charakteristické jsou posuny v prózách Arnošta Lustiga, v jehož pozdních dílech se ztrácí autenticita a je nahrazována jakousi encyklopedií nacistických lágrů, zdánlivě hlubokomyslnými dialogy a erotickými scénami. Sofistikovaněji využíá prvky thrilleru a erotiku autor generace, která se narodila dvacet let po válce a nemá přímou ani zprostředkovanou zkušenost $s$ šoa, Jonathan Littell v románu Laskavé bohyně. Jeho obraz nacistických zločinů vůči Židům je podán očima pachatele, který své činy rafinovaně relativizuje. Umělecky nejodvážnější je ve srovnání s předchozími texty próza Littellova vrstevníka Igora Ostachowicze Noc živých Židỉ. I ona pracuje s postupy popkultury, ale využívá také humoru a ironie a klade, podobně jako Topolova Sestra, provokující aktuální otázky.

\section{Prameny}

LITTELL, Jonathan

2008 Laskavé bohyně; přel. Michala Marková (Praha: Odeon)

\section{LUSTIG, Arnošt}

1958 Noc a naděje (Praha: Naše vojsko)

1991 Nemilovaná (Z deníku sedmnáctileté Perly Sch.) (Praha: Odeon)

2009 Láska a tělo (Praha: Mladá fronta)

2013 Colette. Dívka z Antverp (Praha: Mladá fronta) 
OSTACHOWICZ, Igor

2012 Noc żywych Żydów (Warszawa: Wydawnictwo W.A.B.)

\section{LITERATURA}

(1) ASSMANN, Aleida

2006 Der lange Schatten der Vergangenheit (München: C. H. Beck)

2010 Erinnerungsräume (München: C. H. Beck)

ROSENFELD, Alvin

$\backsim 2011$ The End of the Holocaust (Bloomington: Indiana University Press)

SUCHOMEL, Milan

1992 Literatura z času krize. Šest pohledů na českou prózu 1958-1968 (Brno: Atlantis)

1995 Co zbylo z recenzenta. Literární kritika 1954-1995 (Brno: Vetus Via)

Prof. PhDr. Jiří Holý, DrSc., jiri.holy@ff.cuni.cz, Ústav české literatury a komparatistiky, Filozofická fakulta Univerzity Karlovy, Praha, Česká republika / Department of Czech Literature and Comparative Literature, Faculty of Arts, Charles University, Prague, Czech Republic 